\title{
Advance Copy-Citation
}

Harry Hobbs and George Williams, 'The Participation of Indigenous Australians in Legal Education, 2001-18' (2019) 42(4) University of New South Wales Law Journal (Advance).

\section{THE PARTICIPATION OF INDIGENOUS AUSTRALIANS IN LEGAL EDUCATION, 2001-18}

\author{
HARRY HOBBS* AND GEORGE WILLIAMS**
}

Indigenous Australians face many challenges in accessing and completing a legal education in Australia. Addressing this problem requires a clear empirical picture. However, no comprehensive study exploring the participation of Indigenous Australians in legal education has been conducted for almost two decades. This article rectifies this by presenting the results of a survey on Indigenous Australian students, graduates and staff members within Australian law schools. We find that while Indigenous Australians are increasingly commencing legal studies and graduating from law school, inequities and challenges persist.

\section{INTRODUCTION}

In 1972, Mullenjaiwakka became Australia's first Indigenous law graduate, when he received his degree from the University of Queensland. ${ }^{1}$ Almost 50 years

* $\quad$ Lecturer, Faculty of Law, University of Technology Sydney.

** Dean, Anthony Mason Professor and Scientia Professor, Faculty of Law, University of New South Wales; Barrister, New South Wales Bar. We thank Heather Douglas, Jeni Engel, Melanie Schwartz and the anonymous referees for comments on an earlier draft. We also thank the staff at law faculties and Indigenous support units who responded to our survey request.

1 Angela Melville, 'Educational Disadvantages and Indigenous Law Students: Barriers and Potential Solutions' (2017) 4 Asian Journal of Legal Education 95, 96. Mullenjaiwakka was formally known as Lloyd McDermott. 
later, the number of Indigenous Australian ${ }^{2}$ students participating in legal education in Australia has grown considerably. However, the precise extent of that growth remains uncertain. While several wide-ranging reports exploring Indigenous Australians' participation in tertiary education have been conducted in recent years, no comprehensive survey focusing on legal education has been undertaken since $2000 .^{3}$ This leaves a lacuna that has forced scholars and policymakers to estimate figures based on inconsistent statistics, ${ }^{4}$ or to lament the absence of 'reliable and comprehensive datasets on Indigenous law students' ${ }^{5}$

What is known from successive inquiries and reports is that the enrolment, retention, and graduation rates of Indigenous Australian students across tertiary education generally lag significantly behind their non-Indigenous counterparts. The 2008 Bradley Review of Australian Higher Education, for instance, reported that Indigenous students are 'vastly underrepresented' in tertiary education. ${ }^{6}$ This finding was confirmed in the 2012 Behrendt Review of Higher Education Access and Outcomes for Aboriginal and Torres Strait Islander People, which revealed that Indigenous Australians comprised only $1.4 \%$ of all university enrolments nationwide, ${ }^{7}$ and $0.8 \%$ of all full-time equivalent academic staff. ${ }^{8}$ Smaller studies have found similar results. Wiradjuri scholar Michelle Trudgett noted that in 2008 Indigenous students accounted 'for only $0.6 \%$ of masters by research completions and $0.3 \%$ of doctoral completions'. ${ }^{9}$ More recent reports suggest that the numbers of Indigenous Australians commencing doctoral studies 'has more than doubled in the last decade', ${ }^{10}$ but participation rates still sit below population parity, ${ }^{11}$ and retention and completion rates remain significantly lower than for non-Indigenous students. ${ }^{12}$

2 In this article we use the term 'Indigenous Australian' to refer to both Aboriginal and Torres Strait Islander peoples.

3 See Daniel Lavery, 'The Participation of Indigenous Australians in Legal Education' (1993) 4 Legal Education Review 177; Heather Douglas, 'The Participation of Indigenous Australians in Legal Education 1991-2000' (2001) 24 University of New South Wales Law Journal 485 ('The Participation of Indigenous Australians').

4 Philip Rodgers-Falk and Robert Noomgarm Japaljarri Vidler, 'Growing the Number of Aboriginal and Torres Strait Islander Law Graduates: Barriers to the Profession' (Paper, September 2011) 2.

5 Asmi Wood, 'Law Studies and Indigenous Students' Wellbeing: Closing the (Many) Gap(s)' (2011) 21 Legal Education Review 251, 259-60.

6 Denise Bradley et al, Review of Australian Higher Education: Final Report (Report, December 2008$) 32$.

7 Larissa Behrendt et al, Review of Higher Education Access and Outcomes for Aboriginal and Torres Strait Islander Peoples: Final Report (Report, July 2012) 7.

8 Ibid 8

9 Michelle Trudgett, 'Build It and They Will Come: Building the Capacity of Indigenous Units in Universities to Provide Better Support for Indigenous Australian Postgraduate Students' (2009) 38 Australian Journal of Indigenous Education 9.

10 Toni Schofield, Rebecca O'Brien and John Gilroy, 'Indigenous Higher Education: Overcoming Barriers to Participation in Research Higher Degree Programs' [2013] (2) Australian Aboriginal Studies 13, 23; Nikki Moodie et al, 'Indigenous Graduate Research Students in Australia: A Critical Review of the Research' (2018) 37 Higher Education Research \& Development 805, 805.

11 Rhonda G. Craven and Anthony Dillon, 'Seeding Success in Indigenous Australian Higher Education: Indigenous Australian Students' Participation in Higher Education and Potential Ways Forward' in Rhonda G. Craven and Janet Mooney (eds), Seeding Success in Indigenous Australian Higher Education (Emerald, 2013) 3, 16-7. Behrendt et al (n 7) 8 . 
In response, government and the university sector have developed processes and support mechanisms to encourage and assist Indigenous Australians undertaking higher education. These measures recognise that Indigenous participation in higher education is needed to ensure fair access to the benefits that such education brings, and is an important means of alleviating discrimination and disadvantage. Most recently, Universities Australia, the peak body for the sector, unveiled 'ambitious targets' aimed at lifting university enrolment of Indigenous students by $50 \%$ above the growth rate of non-Indigenous students, and achieving retention and completion rates equal to those of non-Indigenous students by 2025 and 2028 respectively. ${ }^{13}$ These are important goals. Without a clear empirical picture as to the current state of Indigenous Australians' participation in legal education, however, it is impossible to identify whether these targets are appropriate or can be met in this field. Without this empirical picture it is also impossible to identify whether the host of strategies adopted by law faculties, universities and government, are working. This article rectifies this problem by reporting the findings of a survey we conducted examining Indigenous representation amongst the student and faculty body of each of Australia's 38 law schools.

Several surveys have previously explored these questions, but no extensive examination has been undertaken for almost two decades. In Part II, we outline and review the five most significant studies that have been conducted. As we note, these surveys found a small, but steadily increasing number of Indigenous Australians were commencing and completing legal education. They also revealed growth in alternative access and support programs as universities seek to ensure that Indigenous peoples are appropriately represented in legal education. At the same time, these studies faced considerable limitations. In particular, law schools did not always keep accurate data, making it difficult to compare findings, draw broader lessons, or develop appropriate policies and programs to support students.

In Part III we present the results of our survey. We asked each law school to set out the number of Indigenous Australians currently enrolled in a legal degree by program, and the numbers that graduated from their faculty for each year between 2001 and 2017. We also asked whether the law school sets targets for the number of Indigenous students, and whether alternative access or support programs exist to assist Indigenous students undertaking their studies. In addition, we asked schools how many staff identify as an Indigenous Australian. Our survey obtained a high response rate, allowing us to make observations as to the changing nature of Indigenous Australian participation in legal education in Australia. In brief, we find that there has been a steady increase in the numbers of Indigenous Australians commencing and completing an undergraduate legal degree in Australia. However, the numbers of Indigenous postgraduate students and academics remains concerning. These and other observations are outlined in greater detail in Part IV. 


\section{PRIOR SURVEYS}

Assessing the number of Indigenous persons in legal education in Australia is difficult. Surveys and reports have been sporadic, universities have not always kept accurate statistics, and many Indigenous students may not identify as such for a variety of reasons. ${ }^{14}$ Notwithstanding these challenges, successive surveys have revealed that the number of Indigenous Australian students studying and graduating from law schools in Australia has grown. However, those studies have also found that the situation is not uniformly positive. Retention and completion rates, as well as numbers of Indigenous academic staff, are well below their proportion in the population.

\section{A Numbers of Indigenous Law Students and Graduates}

It was not until 1965 that the first Indigenous Australian completed tertiary education. That year, Arrernte activist and public administrator Charles Perkins graduated from the University of Sydney with a Bachelor of Arts. ${ }^{15}$ Perkins' success did not immediately translate into broader access to higher education for Indigenous Australians. Owen Stanley and Geoff Hansen note 'that there were fewer than 10 Indigenous higher education graduates in 1967', ${ }^{16}$ and it was not until 1972 that Mullenjaiwakka became the first Indigenous law graduate.

No data on commencement and completion rates of Indigenous students exist for these early years. The first comprehensive survey exploring the number of Indigenous Australians in legal education in Australia was conducted in late 1990 and early 1991. As part of his graduate studies in Canada, Daniel Lavery wrote to the Deans of each Australian law school. The survey consisted of 14 questions, and focussed on three principal areas:

[T] he number of Indigenous students who have completed or are completing studies in law, the availability of discretionary entrance schemes for Aboriginal and Torres Strait Islander persons to study law, and the availability of any pre-law programmes designed to assist such students to prepare for the study of law. ${ }^{17}$

The survey received a high response rate, with 18 of the then 20 law schools in Australia participating. The results were troubling. Lavery found that of the around 11,000 total students studying undergraduate law in Australia in 1990, only 50 identified as Indigenous. ${ }^{18}$ Underrepresentation was even more pronounced at the postgraduate level. Of the approximately 1,150 students pursing a postgraduate degree in law, only one student identified as Indigenous. ${ }^{19}$ Completion figures were also concerning. By 1990, only 21 Indigenous Australians had graduated with a law degree. ${ }^{20}$ Deriding this figure as 'embarrassingly low', Lavery noted that:

14 The reasons why an Indigenous student may not identify as Indigenous are discussed below in Part II(C), and at nn 87-8.

15 Charles Perkins, A Bastard Like Me (Ure Smith, 1975) 72.

16 Owen Stanley and Geoff Hansen, ABSTUDY: An Investment for Tomorrow's Employment (Report, 1998) $53[5.2 .5 .1]$.

17 Lavery (n 3) 178.

18 Ibid 179. Note, however, that data based on self-identification is unreliable because of underreporting.

19 Ibid 180.

20 Ibid. 
This embarrassment becomes most apparent when one calculates the number of [A]boriginal law graduates required for equitable representation. Based on the 1986 Census figures, true representation would require there be some 1200 such graduates. $^{21}$

The number of Australian law schools grew in the 1990s, ${ }^{22}$ along with alternative access and support programs aimed at enhancing retention and completion rates of Indigenous students. Drawing on these developments, Heather Douglas sought to identify whether these programs were effective and whether the numbers of Indigenous students in legal education was rising. Douglas invited each of the then 26 law schools in Australia offering an LLB qualification to report on the numbers of enrolled Indigenous students and graduates between 19912000 , and to report on what kinds of alternative access mechanisms or support programs each institution had in place. ${ }^{23}$ The survey again received a very strong response rate, with 25 schools replying. Douglas notes, however, that the accuracy of those responses may be called into question:

[O]ver the past 10 years universities have rarely kept accurate statistics of the sort targeted by the questions in the survey. Many of those who completed surveys relied on their personal recollections of numbers of Indigenous students in each year and made estimations based on those recollections. ${ }^{24}$

Nonetheless, the results revealed one clear positive trend: on all measures, the numbers of Indigenous students in legal education increased between 1991 and 2000. Whereas there were only 35 Indigenous first-year LLB students in 1991, by 2000 that number had grown to $89 .{ }^{25}$ Overall, the number of Indigenous students enrolled in a three-year, full-time Bachelor of Laws degree rose from 50 to 256. ${ }^{26}$ Graduation numbers also improved. While Lavery's survey had found that only 21 Indigenous students had graduated with an LLB by 1991, Douglas reported that between 1991 and 2000, that number had risen to $118 .{ }^{27}$

No comprehensive survey has since been conducted, but several attempts to gauge numbers of Indigenous Australians in legal education have been made. In a report for the 2012 Behrendt Review, Philip Rodgers-Falk and Robert Noomgarm Japaljarri Vidler extracted data from the Australian Association of Graduate Employees' UniStats Report. Rodgers-Falk and Vidler note that between 2000 and 2009, the number of first-year Indigenous students studying for a LLB remained relatively constant, sitting at 70 in 2005 and 92 in 2009 (compared to 89 in 2000). ${ }^{28}$ Drawing on this data, but noting 'hugely problematic' retention figures, the authors estimated the total number of Indigenous law graduates at somewhere between 450 and $550 . .^{29}$

21 Ibid.

22 David Barker, A History of Australian Legal Education (Federation Press, 2017) Ch 6; Peter Woelert and Gwilym Croucher, 'The Multiple Dynamics of Isomorphic Change: Australian Law Schools 1987-1996' (2018) 56 Minerva 479, 481.

23 Douglas, 'The Participation of Indigenous Australians' (n 3) 485-6.

24 Ibid 486.

25 Ibid 488.

26 Ibid 488-9.

27 Ibid.

28 Rodgers-Falk and Vidler (n 4) 2.

29 Ibid 1-2. 
In 2013, the Law Council of Australia sought to identify answers to these questions. The Law Council invited members of the Council of Australian Law Deans ('CALD') to detail the number of Indigenous Australian students then enrolled in LLB, JD, LLM and PhD programs at their institution. Obtaining responses from 29 schools, the survey revealed that the data collation challenges that faced Lavery and Douglas had not been resolved: one school reported that they did not keep statistics on this question, and two more could not provide current figures. The survey nonetheless revealed a steady rise in the total number of Indigenous law students. In 26 law schools across the country, 289 Indigenous Australians were enrolled in an LLB, 29 were undertaking a JD, seven an LLM, and five a $\mathrm{PhD} .{ }^{30}$

The most recent survey was conducted by the Indigenous Cultural Competency for Legal Academics Program ('ICCLAP'). Based at the University of New England, ICCLAP is designed to 'increase the inclusion of Indigenous cultural competency in legal education' with the aim of 'improving Aboriginal and Torres Strait Islander student outcomes in law and developing cultural competency in all students'. ${ }^{31}$ In July 2017, the project team wrote to the members of the CALD, inviting them to complete an online voluntary survey. Although the survey primarily focused on the extent to which Indigenous cultural competency was included or incorporated in the content and design of courses provided at each law school, it also asked how many undergraduate and postgraduate students, and academic staff, identify as an Indigenous Australian person. ${ }^{32}$

The ICCLAP survey obtained 20 responses but data collection issues weakened the strength of its results. Seventeen schools responded to the question on numbers of Indigenous students. Only 10 were able to provide statistics, however, with the remainder reporting 'unknown'. ${ }^{33}$ Those 10 schools reported that there were 233 undergraduate and 25 postgraduate students who identify as an Indigenous Australian. All 20 schools who responded to the survey answered the question on Indigenous academic staff. The survey found that there were 11 Indigenous Australian academics working in nine law schools. One in 5 law schools were unable to identify whether they employed any Indigenous academic staff. $^{34}$

\section{B Retention and Completion}

Inadequate data on the numbers of Indigenous Australian law students and graduates means that it is not possible to accurately assess retention and completion rates. However, while the surveys suggest that Indigenous student attrition is falling, it remains a critical challenge for law schools. Lavery's 1990-

30 Council of Australian Law Deans, 'Australian Indigenous Law Student Numbers for the Degrees of LLB, JD, LLM and PhD' (19 March 2013) (source on file with authors).

31 'About ICCLAP', Indigenous Cultural Competency for Legal Academics Program (Web Page)

$<$ http://icclap.edu.au/about $>$.

32 Indigenous Cultural Competency for Legal Academics Program, Law School Survey Report 2017 (Report, October 2017) app 1, questions 6, 12.

33 Ibid 8.

34 Ibid. 
91 study first revealed the scope of the problem. Lavery focused solely on UNSW. Based upon his assessment that UNSW was the 'undoubted leader in the field of Aboriginal Rights in Australian legal education', he considered that UNSW could provide a 'litmus indicator' for Australian schools more broadly. ${ }^{35}$ The limited numbers of Indigenous students across Australia at that time also meant that a broader study was not possible.

The results from UNSW were concerning. Lavery reported that between 1971 (when the university first maintained comprehensive records) and 1990, only 1 in 4 Indigenous students commencing an LLB completed their degree ${ }^{36}$ At other universities, with less established support programs - or no support programs - the number would likely have been even fewer. This conclusion has been borne out by a subsequent study. A decade later, Douglas reported that of the 636 Indigenous students who enrolled in a law degree nationally between 1991 and 2000, only 118 (about $18.5 \%$ ) graduated. ${ }^{37}$

No comprehensive examination of completion rates of Indigenous law students has since been conducted. The limited data suggests, however, that while completion rates may have significantly improved since 1990, they remain troubling. Extracting figures from graduate employee data, Rodgers-Falk and Vidler report that of the 360 commencing Indigenous law students in 2005, 212 (around 59\%) completed their degree. ${ }^{38}$ This methodology may have overestimated the actual figures. The ICCLAP Final Report reveals that data from the Department of Education indicates that between 2003 and 2012, only 26.53\% of commencing Indigenous law students completed their degrees. ${ }^{39}$ Neither the Law Council nor ICCLAP studies sought to assess completion rates, but individual studies do exist. ANU Indigenous legal academic Asmi Wood reported an Indigenous law student retention and completion rate of $100 \%$ at the ANU College of Law in $2010 .{ }^{40}$ If this figure is accurate it is a testament to the commitment of the College, the Tjabal Indigenous Higher Education Centre, and individual academics and support staff to Indigenous students.

\section{Indigenous Australians' Experience in Law School}

Data may be limited, but it is clear that these surveys reveal high attrition and low completion rates among Indigenous law students across the country. Why is this the case? Research exploring these questions, and examining Indigenous Australians' experience of law school more broadly, suggests that a range of interlinked factors negatively affect Indigenous students' entry into and completion of their studies.

All studies recognise that the fundamental cause of persistently poor retention rates is not the decision by individual Indigenous Australians to cease legal

35 Lavery (n 3) 182 n 6.

36 Ibid 182.

37 Douglas, 'The Participation of Indigenous Australians' (n 3) 488; Rodgers-Falk and Vidler (n 4) 2.

38 Rodgers-Falk and Vidler (n 4) 2.

39 Indigenous Cultural Competency for Legal Academics Program, Final Report (Report, 2019) 1 ('ICCLAP Final Report').

40 Wood (n 5) 271. 
education. Rather, low retention rates are 'precipitated by a particular cultural, political and historical context in Australia' ${ }^{41}$ Indigenous Australians are no longer legally or formally excluded from mainstream society, but that context continues to shape the present, affecting Indigenous Australians experiences in legal education. In particular, it contributes to an overriding feeling of alienation among Indigenous law students. ${ }^{42}$ As students explain, they often feel " "disorientated by the system", "under siege", and that they [are] "in an alien environment". ${ }^{43}$

A key contributor to the social and academic isolation many Indigenous law students experience is racism. Indigenous academics have documented their own experiences as students facing racism, on campus and in the classroom, perpetuated by both staff and fellow students. ${ }^{44}$ Racism can be both overt and covert. It can take the form of belittling Aboriginal and Torres Strait Islander culture, knowledge, and perspectives, or drawing negative stereotypes of Indigenous people, ${ }^{45}$ including by identifying defendants as Indigenous where that fact is irrelevant ${ }^{46}$ Racism can also be present in curriculum design, including as to whether Indigenous content is taught in courses, ${ }^{47}$ and the manner in which, or assumptions that underlie the way, it is taught. ${ }^{48}$ As one Indigenous law student in a Brisbane university noted to Heather Douglas and Cate Banks in the 1990s, 'We did about one lecture on Mabo and it was basically defining what Murris can't take. It is not a real threat to you! So it was more in terms of what white Australia had to lose rather than the positives' ${ }^{49}$

Low numbers of Indigenous students and academics amplify these challenges. As Indigenous students have reported, 'there's nothing more isolating than going into a class and being the only Aboriginal student there'. ${ }^{50}$ Even when students do not directly experience racism, they nonetheless perceive themselves as different from the student cohort,${ }^{51}$ making it difficult to connect with fellow students and

Ibid 253.

42 Melanie Schwartz, 'Retaining Our Best: Imposter Syndrome, Cultural Safety, Complex Lives and Indigenous Student Experiences of Law School' (2019) 28(2) Legal Education Review 1, 7; Heather Douglas, “This Is Not Just About Me": Indigenous Students' Insights about Law School Study' (1998) 20 Adelaide Law Review 315, 321 ('This Is Not Just About Me'); Angela Melville, 'Barriers to Entry into Law School: An Examination of Socio-Economic and Indigenous Disadvantage' (2014) 24 Legal Education Review 45, 58-9.

43 Douglas, 'The Participation of Indigenous Australians' (n 3) 490.

44 See for example Nicole Watson, 'Indigenous People in Legal Education: Staring into a Mirror Without Reflection' (2005) 6(8) Indigenous Law Bulletin 4, 5 ('A Mirror Without Reflection'); Phil Falk, 'Law School and the Indigenous Student Experience' (2005) 6(8) Indigenous Law Bulletin 8, 10; Schwartz (n 42) 12; ICCLAP Final Report (n 39) 17.

45 Hannah McGlade, 'The Day of the Minstrel Show' (2005) 6(8) Indigenous Law Bulletin 16, 16.

46 Heather Douglas and Cate Banks, "From a Different Place Altogether": Indigenous Students and Cultural Exclusion at Law School' (2000-1) 15 Australian Journal of Law and Society 42, 48.

47 Watson, ‘A Mirror Without Reflection' (n 44) 6.

48 Heather Douglas, 'Indigenous Legal Education: Towards Indigenisation' (2005) 6(8) Indigenous Law Bulletin 12, 12.

49 Douglas and Banks (n 46) 46. See also Kevin Dolman, 'Indigenous Lawyers: Success or Sacrifice?' (1997) 4(4) Indigenous Law Bulletin 4, 5.

50 Carolyn Penfold, 'Indigenous Students' Perceptions of Factors Contributing to Successful Law Studies' (1996) 7 Legal Education Review 155, 163.

51 Douglas, 'This Is Not Just About Me' (n 42) 323. 
faculty. Indigenous Australians have noted that access and support programs to encourage and nurture Indigenous students and academics in law schools can help students 'see themselves reflected in their education', enhancing their self-esteem, allowing them to realise their full potential and increase the likelihood that they complete their studies. ${ }^{52}$

Financial hardship exacerbates the sense of alienation. Indigenous Australians are more likely than non-Indigenous Australians to come from lower socioeconomic status, ${ }^{53}$ meaning that Indigenous students may struggle to support themselves and undertake community and family responsibilities while engaged in studies. ${ }^{54}$ In interviews, Indigenous Australian law students have reported difficulties in paying for expensive textbooks, ${ }^{55}$ and challenges in securing longterm suitable accommodation. ${ }^{56}$ Others have noted that full-time or even part-time employment can impinge on the time needed to read materials for class, as well as make it difficult to meet class attendance and participation requirements. ${ }^{57}$ Those unable to attend or prepare adequately may feel further isolated from the faculty and institution.

Another challenge that contributes to Indigenous students' sense of alienation is the disjuncture between Indigenous and western knowledge systems. ${ }^{58}$ Aboriginal law is holistic and pervasive; combining elements of 'nature, philosophy and psychology', ${ }^{9}$ it is intimately connected to land; it 'flows from the living [heart]' of country, and sustains that country. ${ }^{60} \mathrm{As}$ such, Indigenous legal knowledges can

include aspects of secrecy; encompass, involve or be contingent on kinship and other special relationships; include ancestral knowledges in a manner unfamiliar to Western knowledge traditions; and be constructed as oral traditions through specific elders, in languages with syntax, grammar and structures completely alien to the English tradition. ${ }^{61}$

Indigenous knowledge systems thus differ radically from traditional western legal discourse, which 'often fail[s] to capture understanding of Indigenous issues, as students or the Indigenous community experience them' ${ }^{62}$ Different approaches to knowledge and teaching can 'silence or ignore' Indigenous voices, ${ }^{63}$ and

52 Watson, 'A Mirror Without Reflection' (n 44) 6.

53 Australian Institute of Health and Welfare, Australia's Welfare 2017: In Brief(Report, 2017) Ch 7.

54 Falk (n 44) 9.

55 Douglas, 'This Is Not Just About Me' (n 42) 342; Douglas and Banks (n 46) 51.

56 Heather Douglas, 'Indigenous Australians and Legal Education: Looking to the Future' (1996) 7 Legal Education Review 225, 227 ('Looking to the Future').

$57 \quad$ Schwartz (n 42) 6.

58 Douglas, 'Looking to the Future' (n 56) 226.

59 Scott Cane, Pila Nguru: The Spinifex People (Fremantle Art Centre Press, 2002) 82.

60 Ambelin Kwaymullina and Blaze Kwaymullina, 'Learning to Read the Signs: Law in an Indigenous Reality' (2010) 34 Journal of Australian Studies 195, 202-3; James Gurrwanngu Gaykamangu, 'Ngarra Law: Aboriginal Customary Law from Arnhem Land' (2012) 2 Northern Territory Law Journal 236, 247.

61 Wood (n 5) 256.

62 Martin Nakata, Vicky Nakata and Michael Chin, 'Approaches to the Academic Preparation and Support of Australian Indigenous Students for Tertiary Studies' (2008) 37 (Supplement) Australian Journal of Indigenous Education 137, 140.

63 Douglas and Banks (n 46) 44. 
'adversely affect learning outcomes for many Indigenous students'. ${ }^{64}$ These challenges are often 'compounded' in law school. ${ }^{65}$ Australian law has legitimated the dispossession of Indigenous land ${ }^{66}$ meaning Indigenous students must study 'the very systems that propped up colonisation and entrench contemporary Indigenous disadvantage' ${ }^{67}$ While many Indigenous students explain that they are interested in studying law in order to assist and support their community in resisting colonial domination, ${ }^{68}$ the experience of learning a system designed to disempower Indigenous communities can be alienating and isolating.

\section{Alternative Access and Support Programs}

Recognising many of these challenges, law faculties and universities have increasingly acted to encourage Indigenous students to enter and succeed in legal education. Such improvements have commenced from a low base. In 1993, Lavery noted that only 11 schools or universities had in place discretionary entry procedures to assist Indigenous students seeking to undertake a law degree and in only two cases, UNSW and Melbourne, were those procedures established prior to 1985. ${ }^{69}$ By 2000, alternative access procedures were more common and access to law school 'more flexible'.$^{70}$ Douglas reports that 24 of the 25 law schools that responded to her survey reported offering discretionary entry procedures, though not all were specifically targeted at Indigenous Australians.

The growth in discretionary entry procedures may have reflected and contributed to a shift in attitudes towards access to law schools. This shift may also have accounted for the rise in Indigenous student participation in legal education. As retention and completion rates attest, however, entry is distinct from success and the Lavery and Douglas studies reveal a concern that Indigenous students did not always receive the support necessary to ensure their success. ${ }^{71}$ Indeed, Lavery's 1991 survey found that no Australian law school offered a preparatory pre-law program for Indigenous students in 1990. ${ }^{72}$ The situation improved over the following decade. Douglas' report revealed that by 2000, 11 law schools operated pre-law or alternative study programs, and a further 2 directed Indigenous students to programs run by UNSW. ${ }^{73}$ Nevertheless, Douglas identified considerable variety in these programs, both in terms of length and content, suggesting a 'somewhat ad hoc approach based more on the personalities involved rather than any systematic, pedagogical examination or program evaluation' ${ }^{74}$

\footnotetext{
64 Wood (n 5) 257.

65 Peter Devonshire, 'Indigenous Students at Law School: Comparative Perspectives' (2014) 35 Adelaide Law Review 309, 310.

66 Falk (n 44) 10.

67 Schwartz (n 42) 10.

68 Douglas, 'This Is Not Just About Me' (n 42) 317-8.

69 Lavery (n 3) 180.

70 Douglas, 'The Participation of Indigenous Australians' (n 3) 493.

71 Ibid 497. See Douglas, 'This Is Not Just About Me' (n 42) 346.

72 Lavery (n 3) 182.

73 Douglas, 'The Participation of Indigenous Australians' (n 3) 498.

74 Ibid 501.
} 
In the absence of a broader Australia-wide study on support mechanisms, academics have detailed their own institution's programs and policies aimed at assisting Indigenous students undertaking legal education. In a 2005 article, for example, members of UNSW's Indigenous Legal Education Committee discussed several recently introduced programs, elaborating on their strengths and ongoing challenges. ${ }^{75}$ Similarly, in 2011, Wood described ANU College of Law's Indigenous Support Scheme, which has operated since 1990, and incorporates both an alternative access program and considerable academic and pastoral support to enrolled students. ${ }^{76}$ Retention and completion rates at ANU suggest that this program is succeeding.

Increasingly, focus has been placed on curriculum development. Amy Maguire and Tamara Young have outlined approaches at Newcastle Law School. Maguire and Young document a survey they conducted to assess the extent to which Indigenous content and perspectives are incorporated into the law school's curriculum. As Maguire and Young argue, including Indigenous content and 'indigenising tertiary education' broadens Indigenous and non-Indigenous students' knowledge and addresses educational disadvantages experienced by Indigenous peoples, ${ }^{77}$ potentially enhancing the likelihood that they continue in their studies. Similarly, in a 2018 article reflecting on 14 years of teaching in Australian law schools, Kate Galloway highlights the importance of embedding Indigenous contexts, perspectives, and law into the curriculum. ${ }^{78}$ As Galloway notes, introducing such material provides 'balance to the Anglo-Australian perspective that dominates the law' 79 as well as signalling a 'definitive commitment to Indigenous Australians through retention and completion' ${ }^{80}$

\section{E Summary of Prior Surveys}

Three key lessons can be gleaned from these surveys and reports. First, data on the numbers of Indigenous Australians either studying law or having graduated with a law degree in Australia is incomplete and in places unreliable. No thorough examination of Australian law schools has been conducted since 2000. Consequently, scholars and policy-makers are reliant on out-of-date surveys and estimates drawn from statistics gathered by graduate employers, or academic articles exploring the experiences of individual institutions. This is inadequate. As Torres Strait Islander scholar Martin Nakata has noted, it is not possible to develop programs and plans to effectively support Indigenous students without accurate

75 Sean Brennan et al, 'Indigenous Legal Education at UNSW: A Work In Progress' (2005) 6(8) Indigenous Law Bulletin 26.

76 Wood (n 5) 263-74; See also Nicole Watson and Asmi Wood, 'Mirror, Mirror on the Wall, Who Is the Fairest of Them All?' (2018) 28 Legal Education Review 1, 15.

77 Amy Maguire and Tamara Young, 'Indigenisation of Curricula: Current Teaching Practices in Law' (2015) 25 Legal Education Review 95, 108-9. See generally Douglas, 'Looking to the Future' (n 56).

78 On the distinction between Indigenous legal issues, Indigenous perspectives, and Indigenous law, see Carwyn Jones, 'Indigenous Legal Issues, Indigenous Perspectives and Indigenous Law in the New Zealand LLB Curriculum' (2009) 19 Legal Education Review 257.

79 Kate Galloway, 'Indigenous Contexts in the Law Curriculum: Process and Structure' (2018) 28 Legal Education Review 1, 4.

$80 \quad$ Ibid 12. 
statistics. ${ }^{81}$ In fact, as Wood has suggested, existing low levels of Indigenous participation in legal education hint that inadequately or poorly informed assumptions have led to faulty policies being implemented'.$^{82}$

Second, despite problems in data collection, a clear trend exists. The surveys reveal that since 1990-91, Indigenous Australians have increasingly commenced and graduated from LLB programs. This is positive and should be celebrated. It does not mean, however, that challenges no longer exist. Without a detailed empirical picture as to the extent of their increasing participation and graduation, its significance is unclear.

Third, although it is not possible to accurately identify retention and completion rates, it is clear that they remain a serious concern. While law schools and universities are increasingly adopting alternative entry and support programs, suggesting a commitment to improve outcomes, the effectiveness of these programs is uncertain. In light of Universities Australia's target to grow the number of Indigenous Australians enrolling in and completing tertiary education, attention needs to be paid to support programs for Indigenous law students. Our survey contributes to this by outlining the current mechanisms and programs.

\section{THE 2018 SURVEY}

Research with and about Indigenous Australians must be conducted in accordance with ethical standards. The Australian Institute for Aboriginal and Torres Strait Islander Studies' ('AIATSIS') Guidelines for Ethical Research in Australian Indigenous Studies ('Guidelines') sets out 14 principles for ethical research founded on respect for Indigenous peoples' inherent rights. Although only mandatory for research sponsored by AIATSIS, the Guidelines constitute best practice and should inform all research in this area. ${ }^{83}$ Two principles were particularly relevant for our study:

Principle 11 - Indigenous people involved in research, or who may be affected by research, should benefit from, and not be disadvantaged by, the research project.

Principle 12 - Research outcomes should include specific results that respond to the needs and interests of Indigenous people. ${ }^{84}$

Our research aims at improving access to legal education for Indigenous Australians and improving outcomes for Indigenous students. It is premised on the proposition made by Nakata and Wood that it is not possible to develop appropriate strategies to encourage and assist Indigenous Australians undertaking legal education without an accurate picture as to their current engagement with

\footnotetext{
81 Martin Nakata, 'The Rights and Blights of the Politics in Indigenous Higher Education' (2013) 23 Anthropological Forum 289, 299.

82 Wood (n 5) 260.

83 Australian Institute for Aboriginal and Torres Strait Islander Studies, 'Guidelines for Ethical Research in Australian Indigenous Studies' (Guidelines, $2^{\text {nd }}$ rev ed, 2012). 
Australian law schools. As a result, our project is consistent with Principles 11 and 12 of the AIATSIS Guidelines. ${ }^{85}$

We conducted our survey by writing to the Dean of each of Australia's 38 law schools, asking them to provide responses to several questions that extend the data collected in the Lavery and Douglas surveys. We sought the following:

1. The number of students who identify as Aboriginal and Torres Strait Islander currently enrolled in the following programs:
a. LLB
b. Graduate Diploma
c. JD
d. LLM (coursework)
e. HDR (both LLM by research, and $\mathrm{PhD}$ )

2. The number of students who identify as Aboriginal and Torres Strait Islander who completed the following programs, for years ending 20012017:
a. LLB
b. Graduate Diploma
c. JD
d. LLM (coursework)
e. HDR (both LLM by research, and $\mathrm{PhD}$ )

3. Whether law schools set targets or quotas of Indigenous law students.

4. The number of employed staff (professional and academic) who identify as Aboriginal and Torres Strait Islander (as of January 2018).

5. Whether alternative access mechanisms and support programs (such as pre-law, tutors/mentors/liaison officers) exist, and if so, how they operate.

The survey obtained a strong response rate, receiving replies from 34 out of 38 law schools (just under 90\%). ${ }^{86}$

Two key limitations exist. First, as with the Lavery and Douglas surveys discussed in Part II, we found that law schools and universities still do not always keep accurate statistics on these questions. Several law schools were able to respond to only part of the survey or reported being unable to locate relevant data. Insufficient data collation had consequences for our results. In particular, as only a few law schools were able to break down numbers of Indigenous graduates by year between 2001 and 2017 we were forced to combine this table. Aggregated

85 We also obtained ethics approval from UNSW's Human Research Advisory Panel: HC No. 180486. Any project involving targeted analysis of data involving Aboriginal and Torres Strait Islander people must also meet several other ethical standards. Our survey was undertaken in accordance with relevant conditions under the National Health and Medical Research Council's National Statement on Ethical Conduct in Human Research and Ethical Considerations in Quality Assurance and Evaluation Activities.

86 Charles Sturt University and the University of Southern Queensland declined to participate. Central Queensland University were not able to provide data. We did not receive a response from Edith Cowan University. Newcastle Law School provided percentage figures which are unable to be tabulated. Therefore, our survey outlines results from 33 law schools. 
data makes it impossible to identity trends in retention and completion rates at individual schools and Australia-wide during this period. Nonetheless, the data remains valuable because it permits a general view on the total number of Indigenous graduates across Australia.

Compounding this issue is a broader challenge. Indigenous students may not always formally identity as Indigenous. The decision not to identify is personal and can be made for a variety of reasons, including because of experiences of racial discrimination and cultural disrespect within the university environment. ${ }^{87}$ Douglas reports that Indigenous students may also be concerned that nonIndigenous colleagues would assume that they gained entry into law school without the requisite marks, or may feel pressured by the university or the institution's Indigenous centre to act as an ambassador in some way when they are already time pressed. ${ }^{88}$ For our purposes, it means that an Indigenous student may not be recorded in university statistics. Consequently, our reported figures likely underestimate the true extent of Indigenous Australians' participation in legal education.

\section{A Numbers of Indigenous Law Students}

Table 1 sets out the numbers of Indigenous students attending Australian law schools in 2018. It outlines the degree program they are undertaking, and the institution they are enrolled at.

87 See above Part II(C). See further Watson and Wood (n 76) 10; Rodgers-Falk and Vidler (n 4) 2-3;

Melville (n 42) 58; Schofield, O’Brien and Gilroy (n 10) 16-7; Sian Powell, 'Survey Finds Racism Still Flourishing on Campuses', The Australian (online, 16 October 2018). 
Table 1: Number of Indigenous Students in Legal Education, 2018

\begin{tabular}{|c|c|c|c|c|c|c|}
\hline \multirow[t]{2}{*}{ University } & \multicolumn{6}{|c|}{ No of students who identify as an Indigenous Australian currently enrolled } \\
\hline & LLB & $\begin{array}{l}\text { Graduate } \\
\text { Diploma }\end{array}$ & JD & $\begin{array}{l}\text { LLM } \\
\text { (coursework) }\end{array}$ & HDR & Tota \\
\hline \multicolumn{7}{|l|}{ New South Wales } \\
\hline Sydney & 13 & - & 5 & 2 & - & 20 \\
\hline UNSW & 60 & - & 5 & 1 & 2 (1 PhD, 1 LLM) & 68 \\
\hline UTS & 24 & 2 & 3 & 1 & 4 & 34 \\
\hline Macquarie $^{89}$ & 32 & - & - & 1 & - & 33 \\
\hline Western Sydney & 25 & - & - & - & $1(\mathrm{PhD})$ & 26 \\
\hline Wollongong & 28 & - & - & 2 & - & 30 \\
\hline UNE & 50 & - & - & 1 & - & 51 \\
\hline Southern Cross & 33 & - & - & 2 & 2 & 37 \\
\hline \multicolumn{7}{|l|}{ Victoria } \\
\hline Melbourne & - & - & 8 & - & - & 8 \\
\hline Monash & 12 & - & 5 & - & - & 17 \\
\hline Deakin & 49 & - & - & - & - & 49 \\
\hline Swinburne & 4 & - & - & - & - & 4 \\
\hline RMIT & - & - & 2 & - & - & 2 \\
\hline Victoria & 4 & - & - & - & - & 4 \\
\hline La Trobe & 3 & - & - & 1 & - & 4 \\
\hline \multicolumn{7}{|l|}{ Queensland } \\
\hline UQ & 14 & - & - & - & - & 14 \\
\hline Griffith & 61 & - & - & - & 1 & 62 \\
\hline QUT & 71 & 6 & - & 5 & 3 (1 LLM, 1 MPhil, 1 PhD) & 85 \\
\hline Bond & 11 & - & 2 & - & $1(\mathrm{PhD})$ & 14 \\
\hline JCU & 30 & - & - & - & - & 30 \\
\hline Sunshine Coast & 9 & - & - & - & - & 9 \\
\hline \multicolumn{7}{|l|}{ Western Australia } \\
\hline UWA & 2 & - & 12 & 2 & - & 16 \\
\hline Murdoch & 9 & - & 1 & - & - & 10 \\
\hline Curtin & 3 & - & - & - & - & 3 \\
\hline Notre Dame & 2 & - & - & - & - & 2 \\
\hline \multicolumn{7}{|l|}{ South Australia } \\
\hline Adelaide & 25 & 2 & - & - & - & 27 \\
\hline UniSA & 5 & - & - & - & - & 5 \\
\hline Flinders $^{90}$ & 13 & - & - & 191 & 1 & 15 \\
\hline \multicolumn{7}{|l|}{ Tasmania } \\
\hline Tasmania & 8 & - & - & - & - & 8 \\
\hline \multicolumn{7}{|l|}{$A C T$} \\
\hline ANU & 9 & 8 & 4 & 10 & $1(\mathrm{PhD})$ & 32 \\
\hline Canberra & 12 & - & - & - & - & 12 \\
\hline ACU & 9 & - & - & - & 1 & 10 \\
\hline \multicolumn{7}{|c|}{ Northern Territory } \\
\hline CDU & 25 & - & - & - & - & 25 \\
\hline Total & 655 & 18 & 47 & 29 & 17 & 766 \\
\hline
\end{tabular}

89 NB: 2019 data.

90 NB: 2017 data.

91 Classified as 'postgraduate'. Not clear whether an LLM or JD. 
Four points are immediately apparent. First, Indigenous Australian students are enrolled at law schools in all states and territories. Nonetheless, New South Wales (299) and Queensland (214) stand out as enrolling a majority of Indigenous law students. By contrast, comparatively few Indigenous students are undertaking law degrees in Victorian institutions (88). This is unsurprising. Victoria has a proportionally smaller Indigenous population, ${ }^{92}$ and five Victorian universities feature in the list of 10 universities with the smallest number of Indigenous students across the country. ${ }^{93}$

However, one Victorian law school is achieving relative success at enrolling Indigenous students. It appears that the majority of Indigenous Australians studying law in Victoria are enrolled at Deakin Law School (49). This may reflect Deakin's innovative approach to Indigenous legal education. Indigenous law students have the option to study through the Institute of Koorie Education, which offers a flexible program consisting of off-campus community-based delivery complemented by local tutors, supported by on-campus intensive study blocks. ${ }^{94}$ In the absence of retention and completion rates it is not possible to assess whether this program is effective at producing Indigenous law graduates, but its success at attracting Indigenous students is striking.

Second, while all law schools have a cohort of Indigenous students, several enrol a significant number. In particular, QUT, UNSW, Griffith, UNE, and Deakin all have at least 49 Indigenous students studying at their institution. Without knowing the precise number of students at each school it is impossible to gauge whether Indigenous students are enrolled at parity with their proportion in the population nationwide $(2.8 \%),{ }^{95}$ or within the region, but it nonetheless constitutes a substantial cohort. This is significant. As we noted above, research has documented that support offered by fellow Indigenous students is 'of exceptional benefit' in helping Indigenous students complete their degrees. ${ }^{96} \mathrm{~A}$ sizeable Indigenous cohort can enhance Indigenous students' sense of belonging, reduce isolation and alienation, and increase non-Indigenous student and staff awareness of Indigenous issues, contributing to culturally safe classrooms. ${ }^{97} \mathrm{~A}$ greater number of Indigenous students may therefore lead to a greater completion rate.

Third, while prior surveys generally focused on the LLB, our survey indicates that Indigenous Australians are undertaking a wide range of postgraduate legal qualifications. However, they are not doing so in significant numbers. Only 29 Indigenous Australians are presently enrolled in a coursework LLM in Australian

92 Australian Bureau of Statistics, Aboriginal and Torres Strait Islander Population Projections, State/Territory (Catalogue No 3238.0, 19 October 2018)

$<$ http://stat.data.abs.gov.au/Index.aspx?DataSetCode=ABORIGINAL_POP_PROJ $>$.

93 Sian Powell, 'Unis Achieve Slow but Steady Increase in Indigenous Students', The Australian (16 October 2018).

94 'Institute of Koorie Education', Deakin University (Web Page) <http://www.deakin.edu.au/courses/ike>.

95 Australian Bureau of Statistics, '2016 Census Shows Growing Aboriginal and Torres Strait Islander

Population' (Media Release, 27 June 2017) <http://www.abs.gov.au/ausstats/abs@.nsf/

MediaRealesesByCatalogue/02D50FAA9987D6B7CA25814800087E03?OpenDocument>.

96 Penfold (n 50) 162. See generally Douglas, 'This Is Not Just About Me' (n 42).

97 Penfold (n 50) 162-6; Wood (n 5) 269. 
law schools, and only 17 are undertaking an HDR program in law. Although the total number of all students undertaking LLM or HDR programs in law is unknown, it is very likely that Indigenous Australian participation is below their proportion in the population. The latest available figures from the Department of Education and Training reveal that in 2016, 57,808 people were enrolled in a $\mathrm{PhD}$ program across all fields in Australia, and 257,549 were undertaking a Master's degree. ${ }^{98}$ By contrast, only 616 Indigenous Australians were enrolled in an HDR course and 1,219 in a Master's program across all fields of study. ${ }^{99}$ Not all of these students were undertaking a legal degree, but these numbers highlight that very few Indigenous Australians are enrolled in postgraduate courses generally.

Fourth, scholars have identified a 'dual system of Indigenous higher education' in Australia. ${ }^{100}$ Under this system, research intensive schools, particularly those in the Group of Eight, ${ }^{101}$ have low numbers of Indigenous students but high completion rates, while other schools have 'high commencement numbers and a high proportion of Indigenous staff', but not necessarily high completion rates. ${ }^{102}$ This does not appear to be the case in relation to commencement numbers in law schools, at least in 2018. As Table 1 illustrates, there is no marked distinction between research-intensive and other universities. Rather, Indigenous Australians are studying at law schools across the country.

Table 2 compares this data to the numbers reported in the Lavery and Douglas surveys. It illustrates that overall, the numbers of Indigenous students undertaking LLB and JD degrees is increasing.

Table 2: Numbers of Indigenous Students in Legal Education

\begin{tabular}{|l|l|l|l|}
\hline & 1990 & 2000 & 2018 \\
\hline No enrolled in LLB & 50 & 256 & 655 \\
\hline No enrolled in JD & 0 & 0 & 47 \\
\hline Total & $\mathbf{5 0}$ & $\mathbf{2 5 6}$ & $\mathbf{7 0 2}$ \\
\hline
\end{tabular}

98 See section 2, table 2.3: Department of Education and Training (Cth), Selected Higher Education Statistics: 2016 Student Data (Web Page, 11 September 2017) <https://www.education.gov.au/selectedhigher-education-statistics-2016-student-data>.

99 See section 6, table 6.1: ibid.

100 Ekaterina Pechenkina, Emma Kowal and Yin Paradies, 'Indigenous Australian Students' Participation Rates in Higher Education: Exploring the Role of Universities' (2011) 40 Australian Journal of Indigenous Education 59, 60.

101 The Group of Eight is a coalition of high quality research-intensive Australian universities. They include: Adelaide University, the Australian National University, Monash University, Melbourne University, Sydney University, the University of Queensland, the University of New South Wales and the University of Western Australia.

102 Pechenkina, Kowal and Paradies (n 100) 64. 
These figures are of course incomplete given the absence of data from five law schools. The actual number of Indigenous Australians undertaking an LLB or JD in 2018 in Australia is therefore likely to be over 800. ${ }^{103}$

It is difficult to assess the proportion of Indigenous law students in Australia. This is because there are no readily available figures on the total number of law students. Neither government agencies nor CALD collate and make public these figures. However, several estimates exist. In 2005, Margaret Thornton suggested that there were around 30,000 students enrolled in Australian law schools. ${ }^{104} \mathrm{In}$ 2017, Neville Carter reported figures gathered by Ernst and Young that suggest 6,510 students commence a law degree each year, ${ }^{105}$ though no estimate of the total student population was provided. For its part, CALD found in 2015 that the total number of Commonwealth-supported places in law stood at just above 28,000. ${ }^{106}$ Considering that law schools are increasingly attracting students to nonCommonwealth supported JD and other programs, the total number of students is much higher. Indeed, the Australian Law Students Association claims to represent 'approximately 40,000 law students'. ${ }^{107}$

Based on CALD's figures, we estimate that there are about 40,000 students studying in Australian law schools. This is a rough figure, and more work should be undertaken to identify a clearer picture. Nonetheless, if there are approximately 800 Indigenous Australians currently undertaking legal education, that equates to $2 \%$ of the total cohort. This is noteworthy. It reveals a considerable improvement from 1990, when Lavery found that Indigenous students comprised only $0.5 \%$ of the total cohort. ${ }^{108}$ Even so, the figure remains below population parity of $2.8 \% .{ }^{109}$

Law faculties are outperforming other disciplines. As noted above, the 2012 Behrendt Review found that Indigenous Australians comprise only $1.4 \%$ of all university enrolments nationwide, ${ }^{110}$ while more recent statistics released by the Department of Education and Training identified Indigenous students as comprising only around $1.2 \%$ of all university students in $2016 .{ }^{111}$ However, while

103 This figure is a rough estimate. 33 law schools reported 702 Indigenous students enrolled in LLB or JD programs. This produces an average of 21.3 Indigenous students per faculty. If we multiply 21.3 by 5 to account for the non-reporting faculties we obtain an estimated figure of 106.5 unrecorded Indigenous students. Adding this figure to our reported 702 students leaves us with an estimated 808.5 Indigenous students enrolled in an LLB or JD in 2018. Although an estimate, this number may be close to the true figure: As noted at $\mathrm{n} 86$, the 5 non-reporting faculties are both small and large and located in Western Australia, Queensland, and New South Wales, states with proportionally greater Indigenous students.

104 Margaret Thornton, 'The Australian Legal Profession: Towards a National Identity' in William LF Felstiner (ed), Reorganisation and Resistance: Legal Professions Confront a Changing World (Hart, 2005) 133, 157.

105 Neville Carter, 'Australian Legal Education Sector: Key Metrics’ (Conference Paper, Australian Academy of Law Future of Australian Legal Education Conference, 11-13 August 2017) 3-4.

106 Council of Australian Law Deans, 'Data Regarding Law School Graduate Numbers and Outcomes' (Paper, 2017) 1.

107 'Welcome to ALSA', Australian Law Students' Association (Web Page) <https://alsa.asn.au/>.

108 Lavery (n 3) 180.

109 Australian Bureau of Statistics (n 95).

110 Behrendt et al (n 7) 7.

111 Compare table 6.1, Department of Education and Training (n 99) with table 2.3, Department of Education and Training (n 98). See also Department of Education and Training, 'Summary of the 2016 Full Year 
Australian law schools may have achieved some successes, particularly in comparison to university-wide metrics, they cannot be complacent. Even if the figure was closer to population parity, it must be noted that parity is not sufficient given historic underrepresentation of the Australian Indigenous population. More work needs to be done to continue to encourage Indigenous Australians to undertake legal education.

\section{B Numbers of Indigenous Law Graduates}

The Lavery and Douglas surveys found that retention and completion rates were a recurrent issue, resulting in substantially fewer Indigenous Australians graduating from their program. As noted above, we were unable to gather graduation data disaggregated by year from every law school, so it is not possible to directly assess completion statistics. Nonetheless, Tables 3 and 4 suggest that attrition rates remain problematic. Table 3 outlines the number of Indigenous law graduates at each school between 2001 and 2017. 
Table 3: Number of Indigenous Graduates, 2001-17 (Total)

\begin{tabular}{|c|c|c|c|c|c|c|}
\hline \multirow[t]{2}{*}{ University } & \multicolumn{6}{|c|}{ No of graduates who identify as an Indigenous Australian, 2001-17 } \\
\hline & LLB & $\begin{array}{l}\text { Grad } \\
\text { Diploma }\end{array}$ & JD & $\begin{array}{l}\text { LLM } \\
\text { (coursework) }\end{array}$ & HDR & Total \\
\hline \multicolumn{7}{|l|}{ New South Wales } \\
\hline Sydney (data from 2006) & 17 & 2 & 3 & 2 & $1(\mathrm{PhD})$ & 25 \\
\hline UNSW & 55 & - & 5 & 4 & 1 (SJD) & 65 \\
\hline UTS (data from 2005) & 27 & 11 & 2 & 1 & - & 41 \\
\hline Macquarie & \multicolumn{6}{|c|}{ Data not available } \\
\hline WSU (data from 2008) & 10 & 3 & - & 1 & - & 14 \\
\hline Wollongong & \multicolumn{6}{|c|}{ Data not available } \\
\hline UNE & 19 & - & 1 & 2 & - & 22 \\
\hline Southern Cross & 27 & 1 & - & - & $1(\mathrm{PhD})$ & 29 \\
\hline \multicolumn{7}{|l|}{ Victoria } \\
\hline Melbourne & 18 & - & 7 & 3 & - & 28 \\
\hline Monash (data from 2003) & 13 & 2 & 2 & 7 & - & 24 \\
\hline Deakin & 33 & - & - & 1 & - & 34 \\
\hline Swinburne & - & - & - & - & - & - \\
\hline RMIT & - & - & 2 & - & - & 2 \\
\hline Victoria & 2 & 1 & - & 1 & - & 4 \\
\hline La Trobe & 10 & - & - & - & $1(\mathrm{PhD})$ & 11 \\
\hline \multicolumn{7}{|l|}{ Queensland } \\
\hline UQ (data 2005-16) & 10 & - & - & - & - & 10 \\
\hline Griffith & 61 & - & - & 1 & $1(\mathrm{PhD})$ & 63 \\
\hline QUT & 53 & 41 & - & 12 & $\begin{array}{l}1 \text { (LLM } \\
\text { research) }\end{array}$ & 107 \\
\hline Bond & 17 & 6 & 1 & 1 & - & 25 \\
\hline JCU & 37 & - & - & - & - & 37 \\
\hline Sunshine Coast & 1 & - & - & - & - & 1 \\
\hline \multicolumn{7}{|l|}{ Western Australia } \\
\hline UWA & 40 & - & - & - & 1 & 41 \\
\hline Murdoch (data from 2005) & 18 & - & - & - & - & 18 \\
\hline Curtin & 6 & - & - & - & - & 6 \\
\hline Notre Dame & 3 & - & - & - & - & 3 \\
\hline \multicolumn{7}{|l|}{ South Australia } \\
\hline Adelaide & 19 & 1 & - & - & - & 20 \\
\hline UniSA & 3 & - & - & - & - & 3 \\
\hline Flinders & 13 & - & - & $2^{112}$ & $1(\mathrm{PhD})$ & 16 \\
\hline \multicolumn{7}{|l|}{ Tasmania } \\
\hline Tasmania (data from 2006) & 16 & 6 & - & - & - & 22 \\
\hline \multicolumn{7}{|l|}{ ACT } \\
\hline ANU & 34 & 85 & 3 & 12 & 2 & 136 \\
\hline Canberra (data from 2004) & 10 & - & - & 1 & - & 11 \\
\hline ACU & 3 & - & - & - & - & 3 \\
\hline \multicolumn{7}{|l|}{ Northern Territory } \\
\hline CDU & \multicolumn{6}{|c|}{ Chose not to provide data } \\
\hline Total & 575 & 159 & 26 & 51 & 10 & 821 \\
\hline
\end{tabular}

112 Classified as 'postgraduate'. Not clear whether an LLM or JD. 
Three points are worth noting. First, the data is incomplete. In addition to the five schools who did not provide figures, three were unable to provide data on this question. Wollongong and Macquarie informed us that they did not retain data on Indigenous graduates, and Charles Darwin chose not to provide statistics because of concerns that any data might be identifiable. Further, as the table notes, several law schools were unable to provide statistics for the full period. ${ }^{113}$ These limitations mean that the number of Indigenous legal graduates between 2001 and 2017 is almost certainly greater than the 821 we identify.

Second, notwithstanding this undercounting, Table 3 suggests that the numbers of Indigenous Australians graduating from HDR programs should be of serious concern. In 17 years, only ten Indigenous Australians graduated with an LLM by research, PhD, or SJD (Doctor of Juridical Science) from 30 Australian law schools. This is problematic in and of itself, but as we discuss below, it also affects the numbers of Indigenous academics.

Third, our reported figure of 821 graduates is inflated by the inclusion of accredited practical legal training courses. Several schools, including ANU, QUT, and UTS offer a practical legal training course styled as a Graduate Diploma that is necessary for graduates to enter legal practice (once a student has already completed an LLB or JD degree). While these schools also offer other Graduate Diplomas, it is likely that the vast majority of graduates of these programs were enrolled in the practical legal training course. The significant numbers of graduates from these courses, particularly at ANU (85), suggests that these schools have been successful in attracting and supporting Indigenous students to completion. However, these courses are often very short and can be completed online. Consequently, the remainder of our paper will not consider the Graduate Diploma figures.

Table 4 aggregates this data and compares it to the Lavery and Douglas surveys, allowing a clearer focus on graduate numbers across time. The table confirms that the number of Indigenous legal graduates increased significantly between 2001 and 2017, let alone from 1990. While each period cannot be directly compared, these findings suggest that law schools are making greater effort and realising greater success at supporting Indigenous students to completion.

Table 4: Numbers of Indigenous Graduates

\begin{tabular}{|l|l|l|l|l|l|}
\hline & & Pre-1990 & $1990-2000$ & $\mathbf{2 0 0 1 - 1 7}$ & Total \\
\hline \multirow{4}{*}{$\begin{array}{l}\text { No of } \\
\text { graduates }\end{array}$} & LLB & 21 & 118 & 575 & $\mathbf{7 1 4}$ \\
\cline { 2 - 6 } & Graduate Diploma & - & - & 159 & 159 \\
\cline { 2 - 6 } & JD & - & - & 26 & 26 \\
\cline { 2 - 6 } & LLM (coursework) & - & - & 51 & 51 \\
\cline { 2 - 6 } & HDR & - & - & 10 & 10 \\
\hline
\end{tabular}

113 Note also that in some cases schools noted that the data on specific programs was not available. 
Two points are worth attention. First, while the numbers of Indigenous LLB graduates have increased considerably, graduation numbers are likely considerably below population parity.

It is difficult to assess the total number of LLB/JD graduates from Australian law schools, as no firm data exists. In the absence of clear statistics, practitioners and policy-makers have long warned of an oversupply of lawyers. ${ }^{114}$ While these reports are often hyperbolic, ${ }^{115}$ the data that does exist suggests that LLB (and JD) completions are increasing. In 2001 there were $4,514 \mathrm{LLB} / \mathrm{JD}$ graduates, ${ }^{116}$ but this number rose to 5,706 in 2012, ${ }^{117}$ and 6,400 in $2014 .{ }^{118}$ A survey conducted by the CALD reported that this number rose further to 7,583 in $2015,{ }^{119}$ and 8,499 in $2018 . .^{120}$

A conservative estimate suggests that around 5,300 students graduated each year with an LLB or JD from an Australian law school for the 17 years between 2001 and 2017. ${ }^{121}$ This produces an overall number of about 90,000 LLB/JD graduates. Even on a conservative estimate, the 601 Indigenous LLB/JD graduates account for only $0.67 \%$ of all total graduates during this period.

Second, while it is not possible to assess attrition rates, they are likely to be high. The total number of LLB graduates between 2001 and 2017 (575) appears too few when considering that 655 Indigenous Australians were enrolled in an LLB in 2018 alone. Law schools may have seen a recent surge in Indigenous enrolment, but available figures suggest that this would not account for the discrepancy.

Rodgers-Falk and Vidler found that first year enrolments of Indigenous Australians in Australian law schools sat at around 90 between 2000 and 2009. ${ }^{122}$ Several law schools have opened since 2009 and increasing government and tertiary sector focus on encouraging enrolment of Indigenous Australians in higher education suggest that it is likely that more than 90 Indigenous students now enrol

114 Emma Ryan, 'Frustration Grows Over Unis "Cashing In" On Law Grad Oversupply', Lawyers Weekly (online, 20 February 2018) < https://www.lawyersweekly.com.au/sme-law/22768-frustration-grows-overunis-cashing-in-on-law-grad-oversupply>; Frank Carrigan, 'Law Schools Sell Graduates Down the River', Australian Financial Review (online, 8 August 2016) $<$ https://www.afr.com/business/legal/thelaw-schools-of-rapidly-diminishing-returns-20160808-gqnday>.

115 Christine Parker, 'An Oversupply of Law Graduates? Putting the Statistics into Context' (1993) 4 Legal Education Review 255; Anne Daly, 'What Is the Recent Evidence on an Excess Supply of Legal Qualifications in Australia?' (2012) 45 Australian Economic Review 441.

116 Edmund Tadros, 'Graduate Glut: 12,000 New Lawyers Every Year', Sydney Morning Herald (online, 14 February 2014) <https://www.smh.com.au/business/graduate-glut-12000-new-lawyers-every-year20140214-32qnm.html>.

117 Ibid.

118 Edmund Tadros and Katie Walsh, 'Too Many Law Graduates and Not Enough Jobs', Australian Financial Review (online, 22 October 2015) <https://www.afr.com/business/legal/too-many-lawgraduates-and-not-enough-jobs-20151020-gkdbyx $>$.

119 Council of Australian Law Deans (n 106) 1.

120 Council of Australian Law Deans, '2018 Data Regarding Law School Graduate Numbers and Outcomes' (Paper, 2019) 1.

121 This figure is reached by replicating known data across the unknown years i.e. in 2001 there were 4,514 graduates. The next known year is 2012. For each year between 2001-11, we take 4,514 graduates as the figure.

Rodgers-Falk and Vidler (n 4) 2. 
each year in law schools across the country. Indeed, as the Department of Education and Training reports, the total number of Indigenous students commencing higher education almost doubled between 2001 and 2016, from 4,128 to $8,219.123$

If we assume that the same trend occurred in law schools, we can estimate that around 2,150 Indigenous students commenced an LLB degree between 2001 and $2018 .{ }^{124} \mathrm{~A}$ law degree is traditionally three or five years. If we remove those who commenced their studies in 2014 or later to account for students who may be in the process of completing their legal studies, we arrive at a total number of potential completed students of 1300 . With 575 graduates, we find a completion rate of $44.2 \% .{ }^{125}$ This is a rough estimate. It is likely that the overall completion rate is lower. Nonetheless, our estimate compares unfavourably to non-Indigenous student completions. Statistics released by the Department of Education and Training reveal that the national completion rate for domestic bachelor students across all courses of study between 2001 and 2016 averaged $84.8 \% .^{126}$ Of course, distinctions will exist across faculties and years. As noted above, ANU reported a completion rate of $100 \%$ in 2010 , while Newcastle Law School reports a retention rate of around $90 \%$.

Table 5 collates and combines our survey responses with those obtained by Lavery and Douglas. To remain consistent with those surveys it focuses on the LLB and JD programs. Notwithstanding challenges in data collection, it reveals several patterns.

123 See appendix 2, table 2.1: Department of Education and Training (Cth) (n 98).

124 This figure is reached by adding the following calculations. Following Rodgers-Falk and Vidler, we assume that 90 students enrolled each year between 2001 and 2009. In line with the Department figures that suggest a $100 \%$ increase in student enrolment between 2001 and 2016 , we assume that 180 students enrolled in 2016 . We then fill the gaps between 2010 and 2015 by assuming a steady increase of 13 students each year. Finally, we assume that numbers remained steady at 180 in 2017 and 2018.

125 Note, however, that some Indigenous LLB students may transfer to another degree rather than discontinue tertiary education entirely. The estimated completion rate discussed here does not include these students, who will still accrue benefits arising from higher education.

126 See Department of Education and Training (Cth) (n 98) app 4.4. Note that the ICCLAP Final Report records that Indigenous student completion rates are $26 \%$ less than for other Australians: (n 39) 1. 
Table 5: Indigenous LLB and JD graduates by law school

\begin{tabular}{|c|c|c|c|c|}
\hline University & Pre-1990 & $1991-2000$ & $2001-17$ & Tota \\
\hline \multicolumn{5}{|l|}{ New South Wales } \\
\hline Sydney & 0 & 3 & $20(2006-17)$ & $23+$ \\
\hline UNSW & 11 & 25 & 60 & 96 \\
\hline UTS & No response & Unknown & $29(2005-17)$ & $29+$ \\
\hline Macquarie & 0 & 0 & Unknown & $0+$ \\
\hline Western Sydney & - & 0 & $10(2008-17)$ & $10+$ \\
\hline Wollongong & 0 & 5 & Unknown & $5+$ \\
\hline Newcastle & Unknown & 2 & Unknown & $2+$ \\
\hline UNE & - & 1 & 20 & 21 \\
\hline CSU & - & - & No response & - \\
\hline Southern Cross & - & 5 & 27 & 32 \\
\hline \multicolumn{5}{|l|}{ Victoria } \\
\hline Melbourne & 1 & 14 & 25 & 40 \\
\hline Monash & 1 & 2 & $15(2003-17)$ & $18+$ \\
\hline Deakin & - & 5 & 33 & 38 \\
\hline Swinburne & - & - & - & - \\
\hline RMIT & - & - & 2 & 2 \\
\hline Victoria & - & - & 2 & 2 \\
\hline La Trobe & - & 0 & 10 & 10 \\
\hline \multicolumn{5}{|l|}{ Queensland } \\
\hline UQ & 1 & 5 & $10(2005-16)$ & $16+$ \\
\hline Griffith & - & 1 & 61 & 62 \\
\hline QUT & Unknown & 5 & 53 & $58+$ \\
\hline Bond & - & 1 & 18 & 19 \\
\hline JCU & - & - & 37 & 37 \\
\hline CQU & - & - & No data & - \\
\hline USQ & - & - & No response & - \\
\hline USC & - & - & 1 & 1 \\
\hline \multicolumn{5}{|l|}{ Western Australia } \\
\hline UWA & 3 & 16 & 40 & 59 \\
\hline Murdoch & - & 4 & $18(2005-17)$ & $22+$ \\
\hline Curtin & - & - & 6 & 6 \\
\hline Edith Cowan & - & - & No response & - \\
\hline Notre Dame & - & 0 & 3 & 3 \\
\hline \multicolumn{5}{|l|}{ South Australia } \\
\hline Adelaide & 2 & No response & 19 & $21+$ \\
\hline UniSA & - & - & 3 & 3 \\
\hline Flinders & - & 6 & 13 & 19 \\
\hline \multicolumn{5}{|l|}{ Tasmania } \\
\hline Tasmania & 2 & Unknown & $16(2006-17)$ & $16+$ \\
\hline \multicolumn{5}{|l|}{$A C T$} \\
\hline ANU & Unknown & 11 & 37 & $48+$ \\
\hline Canberra & - & - & $10(2004-17)$ & $10+$ \\
\hline ACU & - & - & 3 & 3 \\
\hline \multicolumn{5}{|l|}{ Northern Territory } \\
\hline CDU & 0 & 7 & Unknown & $7+$ \\
\hline
\end{tabular}


In 1993, Lavery noted that UNSW provided 'over half' of the total Indigenous law graduates in Australia. ${ }^{127}$ Table 5 illustrates that UNSW has maintained its strong reputation for attracting and graduating Indigenous students - the Faculty celebrated its $100^{\text {th }} \mathrm{LLB} / \mathrm{JD}$ graduate in $2018^{128}$ - but no longer retains such a high percentage of the total graduates. ${ }^{129}$ Indigenous Australians have graduated, though not necessarily in large numbers, from law schools across the country. While it is not possible to determine completion rates at individual universities, several schools can be proud of their successes in supporting Indigenous Australians undertaking legal qualifications. At least four schools have graduated over 50 Indigenous Australian students in LLB and JD programs: UNSW, Griffith, UWA, and QUT.

Second, in every law school that reported figures, graduation numbers increased over the three measured periods. Of course, no direct comparison can be undertaken because these periods differ widely, but this fact nonetheless suggests an increasing commitment and effort at ensuring Indigenous students complete their legal education. The results at several schools are particularly noteworthy. For instance, while only 1 Indigenous Australian had graduated with an LLB from Griffith Law School prior to 2000, a further 61 Indigenous Australians have completed the degree since that year. QUT and UNE have seen similarly impressive results, increasing graduates from 5 to 58 and 1 to 21 respectively.

Overall, our survey reveals that Indigenous Australians are increasingly commencing and graduating with legal qualifications from Australian law schools. Significantly, it appears that Indigenous students are undertaking an LLB or JD program at near their proportion of the total Australian population. More students are also completing their studies. Whereas only 21 Indigenous Australians had graduated with an LLB in 1990, that number stands today at least at 714 .

\section{Access and Support Programs}

Law schools and universities are making a concerted effort to encourage Indigenous Australians to commence legal education and to arrest attrition rates. Almost every school reported that they, or their university, offer alternative access and support programs for Indigenous students. While considerable diversity exists within these programs, their existence signifies a clear commitment on behalf of faculties and universities to support Indigenous students. That commitment does not, however, generally stretch to setting targets to encourage participation of Indigenous Australians. Although Universities Australia has recently set targets aimed at lifting university enrolment of Indigenous Australians, ${ }^{130}$ only two schools reported setting targets. The results are set out in Table 6 .

127 Lavery (n 3) 180.

128 Belinda Henwood, 'UNSW Law Celebrates 100 Indigenous Graduates', UNSW Newsroom (Web Page, 2 April 2019) <https://newsroom.unsw.edu.au/news/business-law/unsw-law-celebrates-100-indigenousgraduates>.

129 Reiterating the challenge of data collection, the Director of Indigenous Legal Education at UNSW notes that the Faculty of Law statistics are incomplete, estimating that at least 104 Indigenous Australians have graduated with an LLB/JD at UNSW (on 2018 figures).

130

Universities Australia (n 13) 14. 
Table 6: Alternative Access and Support Programs

\begin{tabular}{|c|c|c|c|c|c|}
\hline \multirow[t]{2}{*}{ University } & \multirow[t]{2}{*}{ Targets? } & \multirow[t]{2}{*}{$\begin{array}{l}\text { Alternative } \\
\text { Access }\end{array}$} & \multicolumn{3}{|c|}{$\begin{array}{l}\text { Is there a support program? } \\
\text { Who is it conducted by? }\end{array}$} \\
\hline & & & Faculty & University & Other \\
\hline Adelaide & No & Yes & Yes & & \\
\hline$A C U$ & No & No & & Yes & \\
\hline ANU & No & Yes & Yes & & \\
\hline Bond & No & Yes & Yes & Yes & \\
\hline Canberra & No & Yes & Developing Role & Yes & \\
\hline CDU & No & Yes & Yes & Yes & \\
\hline Curtin & No & Yes & & Yes & \\
\hline Deakin & No & Yes & & Yes & \\
\hline Flinders & No & & & & \\
\hline Griffith & No & Yes & Yes & Yes & \\
\hline Macquarie & No & Yes & Developing Role & Yes & \\
\hline Monash & No & Yes & Yes & Yes & \\
\hline Murdoch & No & Yes & \multicolumn{3}{|l|}{ Not answered } \\
\hline Newcastle & Yes - University & Yes & Yes & Yes & \\
\hline UNSW & Informally - Faculty & Yes & Yes & Yes & \\
\hline Notre Dame & Not answered & Yes & & Yes & \\
\hline UQ & No & Yes & & Yes & \\
\hline QUT & No & Not answered & Yes & Yes & \\
\hline RMIT & No & Yes & & Yes & \\
\hline Sydney & No & Yes & & Yes & \\
\hline Swinburne & No & Yes & & Yes & \\
\hline SCU & No & Yes & & Yes & \\
\hline USC & No & Yes & & Yes & \\
\hline UniSA & No & Not answered & & & $\begin{array}{l}\text { South } \\
\text { Australian } \\
\text { Law } \\
\text { Society }\end{array}$ \\
\hline UWA & No & Yes & Yes & Yes & \\
\hline Wollongong & No & Yes & Yes & Yes & \\
\hline
\end{tabular}


Table 6 reveals a significant increase in support programs since the Lavery and Douglas surveys. While Douglas reported that 11 schools offered alternative access programs, 22 out of the 23 schools that responded to this question in our survey indicated that they offer such schemes. These programs generally involve students undertaking an additional period of preliminary study. For instance, Adelaide Law School offers a one-year university preparatory program through Wirltu Yarlu Aboriginal Education for students to gain entry to the LLB program. ${ }^{131}$ Bond Law School adopts a similar approach, offering a Diploma of Legal Studies through which two current members of the LLB cohort have transitioned. Other schools, including the University of Queensland and Southern Cross University, offer dedicated scholarships for Indigenous students undertaking pre-law and LLB programs. ${ }^{132}$

Alternative access programs at UNSW are particularly comprehensive. The university offers a Winter School Outreach Program. ${ }^{133}$ This one-week, residential program is designed for Indigenous high school students across Australia in Years 10-12 who are considering enrolling in university. Run annually in the mid-year break, the program is offered across ten Faculties, including the law school, and is free for all participants. The program appears to be very successful at encouraging and preparing students to enrol in the law school. Nura Gili, UNSW's Indigenous Programs Unit, reports that around $30 \%$ of the annual intake of undergraduate students at UNSW are Winter School graduates. ${ }^{134}$

The Faculty also operates a pre-law residential program, coordinated by Nura Gili. The free 3.5 week program is run for Indigenous high school leavers or mature-aged students from across Australia who want to study a combined law degree. Numbers in this program vary between 6 to 25, with an average class sitting around 12 students. Admission is based on a formal application, including school reports, references, a personal statement, and confirmation of Aboriginality, though almost all applicants are offered places. The course aims at developing introductory legal knowledge and skills to equip pre-law students for early-year law studies, as well as develop general academic and organisational skills to facilitate transition to university. Students who complete the Pre-Law Program generally progress into the combined law degree or the Humanities Pathway Program - a one-year enabling program that provides a pathway into academic study in arts, social sciences and law. Nura Gili provides advice and referrals about other tertiary education options to students who do not receive an offer into one of these programs.

Law schools are continually evaluating and developing Indigenous access programs. In January 2018, for instance, Charles Darwin University commenced

131 University of Adelaide, 'University Preparatory Program', Wirltu Yarlu Aboriginal Education (Web Page) $<$ https://www.adelaide.edu.au/wirltu-yarlu/degrees/upp/>.

132 'Scholarships', University of Southern Queensland (Web Page) <https://www.usq.edu.au/scholarships>; 'High Degree by Research', University of Queensland TC Beirne School of Law (Web Page) $<$ https://law.uq.edu.au/research/higher-degrees-research $>$.

133 Brennan et al (n 75) 27.

134 'Igniting Ambitions at Winter School', UNSW Newsroom (Web Page, 3 July 2014) $<$ https://newsroom.unsw.edu.au/news/students/igniting-ambitions-winter-school $>$. 
an Indigenous Pre-Law and Mentoring Program. Designed to assess whether candidates should be offered a place in the LLB as well as to prepare students to succeed in their studies, the program involved intensive focus on legal skills, content-specific presentations from academics and practitioners, visits to the Northern Territory Supreme Court, an oral presentation before the Director of the Aboriginal Justice Unit, and a debate before a former Supreme Court Justice. ${ }^{135}$ At the end of the program, six of the seven participants were offered places in Charles Darwin University School of Law. ${ }^{136}$

Faculties and universities are also expanding support offered to Indigenous students during their studies. Twenty-two schools reported that support programs are run either directly by the faculty, through the university, or a combination of both. Considerable variety exists.

Some schools employ a dedicated Indigenous support officer. QUT School of Law, for instance, employs an Indigenous Project Officer on a 0.8 fractional basis, whose responsibilities are split between undergraduate $(0.6)$ and postgraduate $(0.2)$ students. Working in partnership with the Oodgeroo Unit, QUT's Indigenous Education Unit, the Indigenous Project Officer provides academic and pastoral support to Indigenous students, from pre-entry through to completion. ${ }^{137}$ Adelaide Law School also provides its own Indigenous Student Liaison Officer, whose role includes offering academic support for Indigenous students in collaboration with Wirltu Yarlu. ${ }^{138}$ Charles Darwin University School of Law does not employ a dedicated staff member, but one academic is responsible for maintaining regular contact with Indigenous students, providing additional academic support where relevant, and discussing student feedback with lecturers in other units. All Indigenous students are also allocated a professional mentor. At UNSW, a fulltime, education-focused academic staff member is appointed as Director of Indigenous Legal Education. Working in conjunction with Nura Gili, this staff member teaches into all of the faculty's Indigenous student programs, and provides academic, pastoral, and administrative support to Indigenous law students. A recent survey of Indigenous students and graduates revealed that this staff member has been critical in supporting student retention and completion. ${ }^{139}$

Recent developments at the School of Law and Justice at Canberra University indicates the dynamism of this area. In 2017, the School entered into a memorandum of understanding with the ACT Supreme Court, Magistrates Court, Law Society and Bar Association, and ANU College of Law to develop a mentoring program for Indigenous law students. Several other schools are also

135 Ben Grimes, 'A Strong Start: The CDU Indigenous Pre-law and Mentoring Program' (2018) 3 Balance: The Northern Territory Law Society Magazine 18, 18-20.

136 Ibid 20.

137 Queensland University of Technology, Indigenous Student Success Programme: 2017 Performance

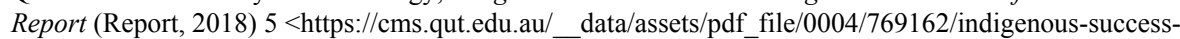
program-2017.pdf>.

138 'About Wirltu Yarlu', Wirltu Yarlu Aboriginal Education: University of Adelaide (Web Page) $<$ https://www.adelaide.edu.au/wirltu-yarlu/about/>; 'Uni Leads Drive to Attract Indigenous Law Students', Adelaidean (Web Page, May 2008) $<$ https://www.adelaide.edu.au/adelaidean/issues/25661/news25694.html>. 
developing their support programs. For example, researchers at Wollongong and Griffith are engaged on a joint project to identify best practice approaches. Project funds have been used to employ two Indigenous undergraduate law students as research assistants, and the team presented initial findings at the Law and Society Conference in Toronto in 2018. Similarly, in consultation with Walanga Muru, Macquarie University's Aboriginal and Torres Strait Islander Student Engagement and Strategy Office, the Macquarie Law School funded two first-year students to attend the National Indigenous Leadership Conference in Western Australia in 2018. It is clear that law schools and universities are increasingly committed to assisting their Indigenous students.

That commitment does not necessarily extend to setting targets or quotas. As Table 6 demonstrates, only two schools reported that they, or their university, set targets for the number of Indigenous law students, while none reported setting a quota. UNSW sets an informal target of achieving population parity in their undergraduate program, while Newcastle University's Strategic Plan identifies a 'key measure of success 2020' as achieving parity of participation of Indigenous students with the proportion of Indigenous people in the Newcastle region. ${ }^{140}$

Although they may not employ targets, several other law schools informed us that they are committed to increasing the participation, retention, and completion rates of Indigenous law students. For instance, Sally Wheeler, Dean of ANU College of Law noted that while the College does not set targets, the University's Strategic Plan aims to substantially increase the recruitment and success of Indigenous undergraduate and postgraduate students, and Indigenous academic staff, across all disciplines and professions. ${ }^{141}$ In 2011, Asmi Wood outlined that the College's then Reconciliation Action Plan aimed at 'achieving national population parity for undergraduate Indigenous law students by 2016'. ${ }^{142}$ Similarly, Wendy Lacey, UniSA Law School Dean, noted that the university is presently setting targets that will be incorporated into the next Strategic Plan. Likewise, Holly Doel-Mackaway, Lise Barry and Emma Hardcastle noted that Macquarie Law School is developing an Indigenous Engagement Strategy which will aim to set targets and quotas in line with Macquarie University's Indigenous Strategy 2016-25. ${ }^{143}$ Finally, although QUT may not set targets for Indigenous students, the numbers are measured. John Humphrey, QUT Law School Dean, informed us that Indigenous student numbers and employed staff are part of his key performance indicators.

\section{Numbers of Indigenous Staff}

We also asked each law school to provide the number of staff members they employ who identify as an Indigenous Australian. Indigenous Australians are underrepresented at academic and professional staffing levels in Australian

140 University of Newcastle, 'NeW Futures Strategic Plan 2016-2025' (2016) 5.

141 See Key Initiative 2.4: Australian National University, 'Strategic Plan 2019-2022' (2019) 19.

142 Wood (n 5) 273.

143 Macquarie University, 'Macquarie University Indigenous Strategy 2016-2025: Baduwa (Aspire), Manawari (Discover), Djurali (Evolve)’ (2016). 
universities. The Behrendt Review found that in 2010 Indigenous Australians comprised only $0.8 \%$ of all full-time equivalent academic staff and $1.2 \%$ of general university staff. ${ }^{144} \mathrm{We}$ did not ask schools to detail their entire workforce, so it is not possible to assess the proportion of Indigenous staff. Nonetheless, our survey reveals that the numbers of Indigenous staff at Australian law schools are very low.

Only 25 schools responded to this question. ${ }^{145}$ The Australian Catholic University, Monash, Murdoch, and Wollongong reported that the number was either not available or unknown. Of the 21 schools who provided figures, 9 did not employ any Indigenous Australians who identify as such. ${ }^{146}$ The remaining 12 reported employing 23 Indigenous staff members. While the majority are undertaking continuing academic roles, several are employed in sessional positions, or as professional staff. Informally, several respondents noted that availability issues around the lack of Indigenous academics leave most law schools competing to employ the few such academics that exist.

\section{OBSERVATIONS}

Six key observations can be drawn from our survey. First, our study faced the same key limitation as previous studies: faculties and universities do not always keep statistics on these questions. It is not clear why this is the case. Although Indigenous students may not always identify as such, it should be relatively simple for faculties and universities to collect and retain de-identified data on those that do. Indeed, it is important that law schools undertake this role. The development of effective programs to encourage and support the success of Indigenous students relies on the availability of accurate data. Law schools or Indigenous Education Units embedded in universities should therefore keep consistent, standardised data on certain key issues in this area to enable assessment and appropriate decisionmaking. At a minimum this could include numbers of commencing and graduating Indigenous Australian students per program, per year.

Owing to the significance of this issue, it may be appropriate that data collection is led by a national organisation. As the peak body of Australian law schools, CALD could undertake this role. CALD has a long-standing, ongoing body of work designed to improve the legal educational outcomes of Indigenous students. Indeed, as we noted above, the Council has previously explored this issue by undertaking its own survey.

Second, there has been a steady increase in the numbers of Indigenous Australians commencing and completing an undergraduate legal degree in Australia. However, those numbers remain below parity with the proportion of

144 Behrendt et al (n 7) 8.

145 The schools that responded were: Adelaide, Australian Catholic University, ANU, Bond, Canberra University, Charles Darwin University, Curtin University, Deakin, Flinders University, Griffith, Monash, Murdoch, UNSW, UQ, QUT, RMIT, Sydney, Swinburne, Southern Cross University, University of the Sunshine Coast, UniSA, UWA, Western Sydney, and Wollongong.

146 Canberra University, Charles Darwin University, Curtin University, Macquarie, UQ, RMIT, Swinburne, Southern Cross University, and the University of the Sunshine Coast. 
Indigenous Australians in the population. Certainly, more work is required, but the steady increase is nonetheless significant and suggests that the sustained effort by faculty and universities in developing and enhancing pre-law programs and other support mechanisms is producing substantial benefit. Considering historic underrepresentation, however, more work is needed.

The third key observation our survey reveals is that there is an inconsistent sector-wide performance when it comes to attracting Indigenous students and supporting them to completion. Only five law schools - QUT, UNSW, Griffith, UNE, and Deakin - had at least 49 Indigenous Australian students enrolled in LLB programs in 2018. Together, these five schools accounted for over $41 \%$ of the total number of Indigenous Australian students in legal education from the 33 law schools that provided figures. When only LLB programs are considered, that number rises to $44.4 \%$ of the total.

By contrast, 11 law schools enrolled 10 or fewer Indigenous Australian students in 2018. ${ }^{147}$ Every law school has its own challenges in attracting Indigenous students. Some of these schools are small or relatively new, and their total student population is low. Others are situated in states with relatively few Indigenous peoples. Nonetheless, that a third of our survey respondents combined to enrol only 59 Indigenous Australian students in 2018 is concerning. As we noted earlier, research demonstrates that a sizable Indigenous cohort can reduce Indigenous students' feelings of isolation and alienation, improving the likelihood that students will complete their degree. Law schools that enrol few Indigenous Australians may therefore need to develop additional support mechanisms to assist their students.

Fourth, although our data is incomplete, it is clear that the number of Indigenous academics is very low. Moreover, the Indigenous staff that do exist are not spread widely across institutions. Only twelve of the 25 schools that responded to this question reported that they employed Indigenous Australians in either academic or professional roles.

The dearth of Indigenous academics has negative consequences for students. Teachers can exacerbate or ease Indigenous students' sense of cultural alienation and isolation. ${ }^{148}$ While all instructors should be culturally competent, Indigenous lecturers may be more likely to understand and appreciate the specific concerns of Indigenous students. ${ }^{149}$ The presence of Indigenous Australian academics may also improve Indigenous students' self-esteem and encourage them to enter and continue in their studies. Research shows that role models are vitally important for Indigenous Australians in accessing and succeeding in higher education. ${ }^{150}$

147 Melbourne, Swinburne, RMIT, Victoria, La Trobe, Sunshine Coast, Curtin, Notre Dame, UniSA, Tasmania, and ACU.

148 Douglas, 'This Is Not Just About Me' (n 42) 326-30. See further above nn 50-2

149 Galloway (n 79) 5.

150 Watson, 'A Mirror Without Reflection' (n 44); Ekaterina Pechenkina and Ian Anderson, 'Background Paper on Indigenous Australian Higher Education: Trends, Initiatives and Policy Implications' (Background Paper, Review of Higher Education Access and Outcomes for Aboriginal and Torres Strait Islander People, September 2011) 4. 
Law schools also have a broader societal responsibility to nurture and support Indigenous academics. As Nicole Watson has argued, the presence of Indigenous law faculty can help to ameliorate and overcome legacies of institutional academic racism. ${ }^{151}$ Furthermore, as law schools enjoy a 'virtual monopoly' over the supply of legal education, law schools have a 'profound obligation to ensure that the future profession can accommodate the legal needs of our entire society, including Indigenous communities' ${ }^{152}$ In this sense, the lack of Indigenous academics means that non-Indigenous students also suffer. An absence of Indigenous academics means that all students will miss out on the unique contribution provided by Indigenous staff. This is particularly the case as efforts continue at embedding Indigenous perspectives, content, and law into the curriculum. Without a sufficient number of qualified academics, these strategies cannot be run effectively and all students' studies will be deficient.

Similarly, low numbers of Indigenous legal academics place greater pressure on those that do exist. An Australian-wide survey of Indigenous academics revealed that Indigenous scholars often undertake a wide range of non-traditional academic work, including supporting students, non-Indigenous colleagues, and community. ${ }^{153}$ In addition to the challenge of managing task overload, this valuable work is not always recognised within the academy and 'exact[s] professional costs' by 'slowing the research productivity required for promotion' ${ }^{154}$ While this survey was not limited to legal academics, it is likely that the same problems recur. ${ }^{155}$

Fifth, although the increasing numbers of Indigenous undergraduates is a positive story, the situation at the postgraduate level is concerning. Between 2001 and 2017, only nine Indigenous Australians completed a $\mathrm{PhD}$ in law at an Australian law school, and only 17 are currently undertaking a PhD. It has become increasingly rare for legal academics to be appointed without holding a $\mathrm{PhD}$. As a result, these figures help explain the dearth of Indigenous legal academics, and also suggest that their absence will not be rectified quickly. If law schools are committed to increasing the number of Indigenous academic staff, faculties and universities should devote resources and develop strategies to ensure that the rise in numbers in undergraduate programs is equally reflected at the postgraduate level.

Sixth, our survey reveals that faculties and universities have generally refrained from adopting targets as a means to increase numbers of Indigenous students. This approach is inconsistent with recent developments. As noted earlier, in 2017, Universities Australia set targets to lift rates of university enrolment, retention, and completion of Indigenous Australian students. ${ }^{156}$ This strategy follows the 2012 Behrendt Review, which recommended that government set

151 Watson, 'A Mirror Without Reflection' (n 44) 6. See also Irene Watson, 'Some Reflections on Teaching Law: Whose Law, Yours or Mine?' (2005) 6(8) Indigenous Law Bulletin 23.

152 Watson, ‘A Mirror Without Reflection' (n 44) 6.

153 Christine Asmar and Susan Page, 'Sources of Satisfaction and Stress among Indigenous Academic Teachers: Findings from a National Australian Study' (2009) 29 Asia Pacific Journal of Education 387, 394.

154 Ibid.

155 See also ICCLAP Final Report (n 39) 17; Watson and Wood (n 76) 7-8.

156 See Universities Australia (n 13). 
national targets for Indigenous student and staff enrolments at their proportion in the population, ${ }^{157}$ and that universities use the population parity targets to set their own targets. ${ }^{158}$ Despite this, only Newcastle University has formally adopted a population parity target. Significantly, our survey found that the law school is meeting that target: Indigenous students comprise $4.2 \%$ of all current students, a figure that rises to $9 \%$ in the 2018 cohort.

In light of the Behrendt Review recommendations, Universities Australia's 2017 Strategy, and the continuing low numbers of Indigenous academic staff, law schools should consider adopting targets for postgraduate and HDR students. Publicly stated targets will help drive investment of resources to ensure that commencing students are supported throughout their studies. Targets at this level could rectify poor representation and also lead to greater numbers of Indigenous staff.

\section{CONCLUSION}

In this paper we have reported the findings from a survey provided to the Deans of each of Australia's 38 law schools. Our survey explored the extent and scope of Indigenous Australians' participation in legal education between 2001 and 2018. In doing so, we updated and extended the work carried out in previous surveys conducted by Lavery and Douglas. Our survey was not able to gather data from every faculty, but it constitutes the most significant attempt at answering these questions since 2000. In doing so, it provides an empirical picture as to the state of Indigenous Australians in legal education in Australia.

Our survey reveals several positive stories. First, Indigenous Australians are increasingly commencing LLB and JD degrees. In 2018, there were 702 Indigenous Australians enrolled in an LLB or JD program at 33 Australian law schools. ${ }^{159}$ Drawing on our findings, we estimate that there are over 800 Indigenous Australian students undertaking these degrees. This is a significant increase from 1990 and 2000, when only 50 and 256 Indigenous students were enrolled.

More Indigenous Australian students are also completing their studies. Only 21 Indigenous Australians had graduated with an LLB degree prior to 1990. Between 1991 and 2000 this number rose to 118. Since 2001, at least 605 Indigenous Australians have completed an LLB or JD. Graduation numbers still lag behind population parity, but this increase is considerable. Overall, at least 740 Indigenous Australians have completed an LLB or JD from an Australian law school. This figure will rapidly increase given that 702 Indigenous law students are currently enrolled in Australia.

However, our survey does identify several concerns. Attrition rates are likely still too high, while the numbers of Indigenous Australian postgraduate students

157 Behrendt et al (n 7) 17 (Recommendation 1).

158 Ibid (Recommendation 2).

159 Macquarie Law School data is from 2019. Flinders Law School data is from 2017. 
and academic staff remain too low. Our survey also reveals that challenges in data collection persist. Faculties and universities do not always keep statistics on these questions and many respondents were unable to provide data. Without accurate data, schools and universities will not be able to develop effective programs and strategies to encourage and support the success of Indigenous Australian law students. Progress is being made, but there is much more yet to be done. 